resist these wreckers, inside and outside of our government, if necessary, with the last drop of their blood.

The spirit of America, with its creative genius, coupled with its humanity, is the beacon light to all mankind. We cannot afford, . the world cannot afford, to have its foundations undermined.

The American Ship of State will sail on and on, if there is a crew in command which will not change the course to the shoals on the left, or to the rocks on the right. The middle course, is the American course.

President SMITH: Thank you, Senator Thurston. It was indeed a privilege to listen to you, and an honor to all to have this address from our distinguished fellow citizen.

Now, with the hope and expectation that we may be able to be with you two years hence, the pioneers bid you a fond farewell. It is my good pleasure to surrender the chair to the Lieutenant Governor.

President Evans: Thank you, Mr. Smith. I can assure the Pioneer Lawmakers that the previous question has not been ordered. We are happy, President Smith, that we could have you with us on this traditional occasion and we hope that you will be back with us two years hence. And, Lloyd Thurston, thanks for a very fine address.

Many musical numbers interspersed the program and were given by the orchestra from the State College of the Blind at Vinton.

The committee previously appointed came forward and escorted the Pioneer Lawmakers from the house chamber.

\title{
MORE IOWA YOUTHS SEEK EDUCATION
}

When Drake University was founded in Des Moines in 1881 it had 270 students. In February, 1947, the number enrolled were 4,572-just another indication of the part education is playing today in fitting youth for life's responsibilities. 
Copyright of Annals of Iowa is the property of State of Iowa, by \& through the State Historical Society of Iowa and its content may not be copied or emailed to multiple sites or posted to a listserv without the copyright holder's express written permission. However, users may print, download, or email articles for individual use. 